\title{
Blooms of the woloszynskioid dinoflagellate Tovellia diexiensis sp. nov. (Dinophyceae) in Baishihai Lake at the eastern edge of Tibetan Plateau
}

\author{
Qi Zhang ${ }^{1}$, Huan $\mathrm{Zhu}^{1}$, Zhengyu $\mathrm{Hu}^{2}$ and Guoxiang Liu ${ }^{1, *}$ \\ ${ }^{1}$ Key Laboratory of Algal Biology, Institute of Hydrobiology, Chinese Academy of Sciences, Wuhan 430072, China \\ ${ }^{2}$ State Key Laboratory of Freshwater Ecology and Biotechnology, Institute of Hydrobiology, Chinese Academy of Sciences, \\ Wuhan 430072, China
}

Freshwater red tides due to dinoflagellates have caused spectacular and regular "summer reddening" in recent years in Baishihai Lake, a temperate, meromictic, meso- or oligotrophic, high-altitude, landslide-dammed, deep lake located at the eastern edge of Tibetan Plateau in China. Based on morphological and molecular analyses, the causative organism has been identified as a new woloszynskioid dinoflagellate, Tovellia diexiensis Q. Zhang et G. X. Liu sp. nov. The vegetative cells are 20-32 $\mu \mathrm{m}$ long and 16-24 $\mu \mathrm{m}$ wide. They have a hemispherical episome and a broadly rounded hyposome with a short characteristic antapical spine. Usually cells are bright red due to the presence of numerous red-pigmented bodies, which often masked the yellowish green discoid chloroplasts. The amphiesma of motile cells comprise mainly quadrilateral, pentagonal or hexagonal thin plates, arranged in 4-5 latitudinal series on the episome, 1 in the cingulum and 4 on the hyposome. Molecular phylogenies based on small subunit ribosomal DNA and large subunit ribosomal DNA (LSU) indicate T. diexiensis from Baishihai Lake to belong to the family Tovelliaceae, which was monophyletic in our LSU phylogenies. During the bloom-forming period in 2005, cell density of T. diexiensis reached $9.15 \times 10^{5}$ cells L ${ }^{-1}$. Astaxanthin and its diester were found to be the major pigments in T. diexiensis, resulting in a characteristic blood-red color of the water in Baishihai Lake.

Key Words: astaxanthin; Baishihai Lake; bloom; ecology; morphological observation; phylogeny; Tovellia diexiensis sp. nov.

\section{INTRODUCTION}

Dinoflagellate blooms usually occur in both nutrientrich marine and freshwater environments (Cantonati et al. 2003). Although freshwater dinoflagellate blooms are much less widespread than in the sea (e.g., Rodriguez et al. 1999), many freshwater blooms, mainly due to Peridinium and Peridiniopsis taxa, have been reported and documented in Japan (Fukuju et al. 1998), Australia (Regel et al. 2004), Israel (Berman-Frank et al. 1994), France
(Rodriguez et al. 1999), and China (Zhang et al. 2011). The woloszynskioid bloom of Tovellia sanguinea Moestrup, Gert Hansen, Daugbjerg, G. Flaim \& D'andrea (= Glenodinium sanguineum Marchesoni) in Lake Tovel, Brenta Dolomites, Italy ever gave a spectacular "reddening of the waters" of the South-West Bay (called Red Bay) in summer, which suddenly ceased in 1964 (Cantonati et al. 2003). The phenomenon was considered unique because
(9) $\$$ This is an Open Access article distributed under the terms of the Creative Commons Attribution Non-Commercial License (http://creativecommons.org/licenses/by-nc/3.0/) which permits unrestricted non-commercial use, distribution, and reproduction in any medium, provided the original work is properly cited.
Received August 1, 2016, Accepted September 7, 2016

*Corresponding Author

E-mail: liugx@ihb.ac.cn

Tel: +86-27-68780726, Fax: +86-27-68780123 
of its regular appearance in summer, except in years with bad weather during the summer months (Marchesoni 1959).

Baishihai Lake (32 $\left.06^{\prime} 31^{\prime \prime} \mathrm{N}, 103^{\circ} 36^{\prime} 53^{\prime \prime} \mathrm{E}\right)$ is located in the northwestern Sichuan Province at the eastern edge of Tibetan Plateau, which is characterized by a windy and semi-arid climate, alpine valleys, and frequent earthquakes (Jiang et al. 2014). It is a barrier lake, and one of several landslide-dammed lakes formed in the upper reaches of the Minjiang River following the 1933 Diexi earthquake ( $\mathrm{M}=7.5)$ (Xu and Wang 2002, Wang et al. 2014). The lake is $2,480 \mathrm{~m}$ above sea level and covers $400,000 \mathrm{~m}^{2}$ with the length of $1,600 \mathrm{~m}$, a width of $250 \mathrm{~m}$, the mean and maximum depths $25 \mathrm{~m}$ and $80 \mathrm{~m}$, respectively. In the summer of 2001, sudden reddening of the waters was first reported. The spectacular red color had caused panic among the local villagers $\mathrm{Xu}$ and Wang 2002). The peculiar "reddening of the waters" has occurred many times in subsequent years and has been reported widely. A documentary film produced by China Central Television (CCTV) described the spectacular sight and tried to explain the mysterious reddening phenomenon (http://search.cctv.com/search.php?qtext=\%E7\% 9 $9 \% \mathrm{BD} \% \mathrm{E} 7 \% 9 \mathrm{~F} \% \mathrm{~B} 3 \% \mathrm{E} 6 \% \mathrm{~B} 5 \% \mathrm{~B} 7 \&$ type=video). The reasons for this phenomenon were unclear and have been associatedwith microbes (e.g., Xu and Wang 2002).

In 2011, we investigated the lake and found the causative organism to be closely related to woloszynskioid dinoflagellates. Its occurrence in the lake and the identity of the pigment causing the red color were also studied.

\section{MATERIALS AND METHODS}

\section{Sampling and preservation}

Water samples were collected at five sampling sites in Baishihai Lake on Sep 1, 2005 site I ( $32^{\circ} 06^{\prime} 47^{\prime \prime} \mathrm{N}, 103^{\circ} 36^{\prime} 31^{\prime \prime}$ E), site II ( $\left.32^{\circ} 06^{\prime} 49^{\prime \prime} \mathrm{N}, 103^{\circ} 36^{\prime} 32^{\prime \prime} \mathrm{E}\right)$, site III $\left(32^{\circ} 06^{\prime} 50^{\prime \prime} \mathrm{N}\right.$, $\left.103^{\circ} 36^{\prime} 33^{\prime \prime} \mathrm{E}\right)$, site IV ( $\left.32^{\circ} 06^{\prime} 32^{\prime \prime} \mathrm{N}, 103^{\circ} 37^{\prime} 01^{\prime \prime} \mathrm{E}\right)$, and site $\mathrm{V}$ $\left(32^{\circ} 06^{\prime} 32^{\prime \prime} \mathrm{N}, 103^{\circ} 37^{\prime} 10^{\prime \prime}\right.$ E) (Fig. 1). Samples of the red water (Fig. 2) were collected using a 5-L Van Dorn sampler. Phytoplankton samples for quantitative analysis were collected in 1,000 $\mathrm{mL}$ bottles and fixed with $1.5 \%$ acid Lugol's iodine solution. Water conductivity was measured in situ using portable INESA DDB-303A Conductivity Meters (INESA, Shanghai, China).

The dinoflagellates were collected at Baishihai Lake for morphological and molecular analyses on Sep 1, 2005 and Aug 20, 2011. We attempted to culture the dinofla-

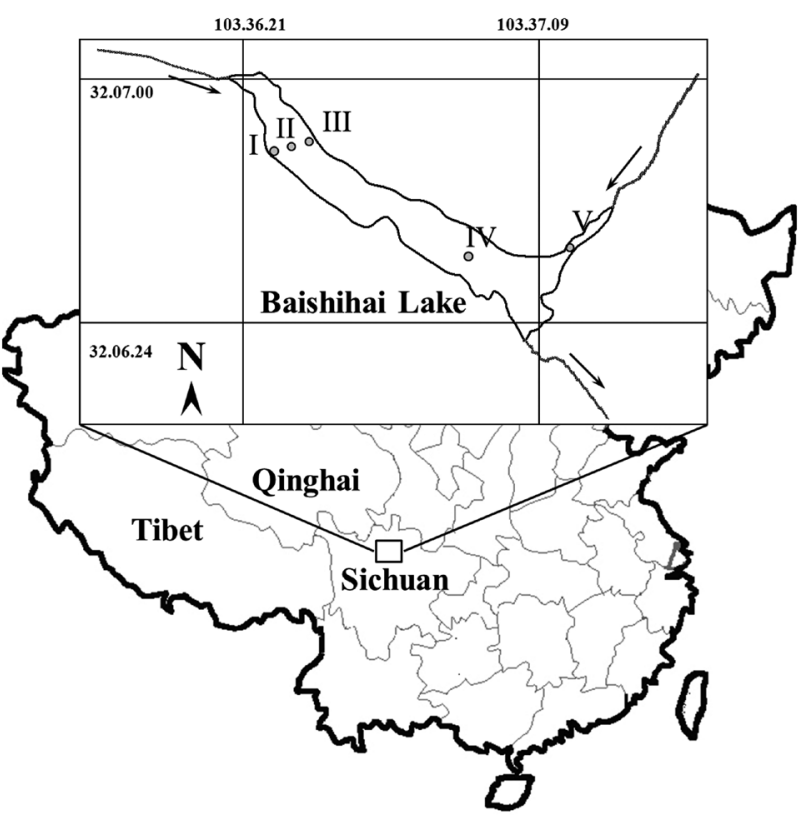

Fig. 1. Locations of Baishihai Lake and sampling sites (I-V). Baishihai Lake is located in the northwestern Sichuan Province at the eastern edge of Tibetan Plateau. Map supplied by the State Bureau of Surveying and Mapping, available at: http://www.sbsm.gov.cn/article/zxbs/ dtfw.

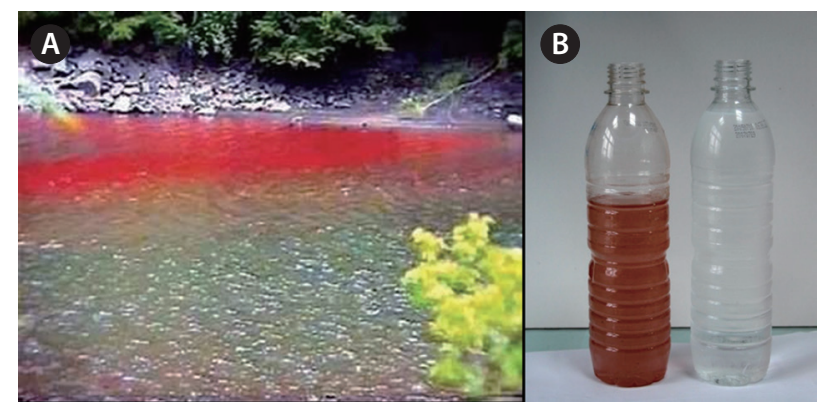

Fig. 2. Bloom of Tovellia diexiensis in Baishihai Lake in 2005. (A) The sudden reddening of the waters in the lake. (B) Sample with dinoflagellate bloom water (left, bloom water; right, pure water).

gellate but were not successful, and subsequent studies were therefore undertaken using natural samples. Samples were preserved in $10 \%$ formalin or $90 \%$ ethanol for morphological and molecular analyses, respectively. Ethanol-fixed samples were subsequently frozen at $-20^{\circ} \mathrm{C}$ until analysis.

\section{Light microscopy}

Cells were observed using differential interference contrast, phase contrast, and epifluorescence microsco- 
py with BG38 Filter (excitation filter, BP $340-380 \mathrm{~nm}$; dichromatic mirror, $400 \mathrm{~nm}$; suppression filter, LP $425 \mathrm{~nm}$ ) on a Leica DM5000B microscope (Leica Microsystems, Wetzlar, Germany). Micrographs were taken with a Leica DFC320 digital camera.

Counts for phytoplankton samples were carried out with an OLYMPUS CX41 microscope (Olympus, Tokyo, Japan) according to Zhang and Huang (1991) and Eker et al. (1999). At each magnification at least 100 individuals of the dominant taxa were counted, which corresponds to a maximum error of about $20 \%$ (Lund et al. 1958).

\section{Chemical analyses}

Water samples for chlorophyll- $a$ analyses were filtered in the field within a few hours of sampling, using Whatman GF/C 0.45- $\mu$ m filters (GE Healthcare, Amersham, Buckinghamshire, UK), and stored at $-20^{\circ} \mathrm{C}$ until the extraction in $90 \%$ acetone and the spectrophotometric analyses (Lorenzen 1967). Total dissolved nitrogen (TDN), ammonium $\left(\mathrm{NH}_{4}-\mathrm{N}\right)$, total dissolved phosphorus (TDP), phosphate $\left(\mathrm{PO}_{4}-\mathrm{P}\right)$, and chemical oxygen demand were measured by spectrophotometric methods (State Environmental Protection Bureau 2002).

\section{Pigment analyses}

Water samples were filtered onto Whatman GF/C 0.45$\mu \mathrm{m}$ filters and immediately stored at $-20^{\circ} \mathrm{C}$. Filters were subsequently transferred to $3 \mathrm{~mL}$ acetone, and left to extract for $24 \mathrm{~h}$ at $4^{\circ} \mathrm{C}$. To identify and determine the composition of pigments, high performance liquid chromatography (HPLC) analyses were performed on a Agilent 1100 system (Agilent Technologies, Santa Clara, CA, USA) with a reverse-phase $\mathrm{C} 18$ column $(\mathrm{C} 18,250 \mathrm{~mm} \times 4.6$ $\mathrm{mm}, 5 \mu \mathrm{m}$; Supelco Discovery, Sigma-Aldrich, Bellefonte, PA, USA) using a slightly modicated method described by Schlüter and Havskum (1997) and Yuan et al. (2002).

\section{Single-cell polymerase chain reaction (PCR) and sequencing}

The sequences of nuclear-encoded rDNA (small subunit ribosomal DNA [SSU] and large subunit ribosomal DNA [LSU]) from the dinoflagellate were determined using the single-cell PCR method. About 10 cells were isolated from ethanol-fixed samples under an inverted Olympus CKX41 microscope (Olympus) for each PCR reaction. Individual cells were then placed in $200-\mu \mathrm{L}$ PCR tubes. DNA extraction was treated with proteinase $\mathrm{K}(\mathrm{pK})$ which is commonly used in molecular biology to digest protein and remove contaminations from preparations of nucleic acid. Details of the method have been described by Ki et al. (2005). The elution volume of DNA used in the PCR was about $5 \mu \mathrm{L}$.

Three sets of PCR primers were used for PCR amplification of SSU rDNA (uP18f, 5'-AACCTGGTTGATCCTGCCAG-3'; uP18r, 5'-TGATCCTTCTGCAGGTTCACCTAC-3'), and partial LSU rDNA (domains D1-D2) (DinFi, 5'-GCATATAAGTAMGYGGWGG-3'; DinRi， 5'-CCGTGTTTCAAGACGGGTC-3') (Logares et al. 2007). PCR amplifications were done using $5 \mu \mathrm{L}$ of the above template DNA, $1 \times$ PCR buffer, $0.25 \mu \mathrm{M}$ dNTP, $0.4 \mu \mathrm{M}$ of each primer, and 0.65 U ExTaq DNA Polymerase (TaKaRa, Dalian, Liaoning, China) in $25-\mu \mathrm{L}$ total volume reactions. The SSU PCR began with $3 \mathrm{~min}$ at $94^{\circ} \mathrm{C}$, followed by 35 cycles of $1 \mathrm{~min}$ at $94^{\circ} \mathrm{C}, 1 \mathrm{~min}$ at $56^{\circ} \mathrm{C}, 1.2 \mathrm{~min}$ at $72^{\circ} \mathrm{C}$, and terminating with a final hold of $5 \mathrm{~min}$ at $72^{\circ} \mathrm{C}$. The LSU PCR temperature profile was equivalent to the SSU except for the annealing temperature of $52^{\circ} \mathrm{C}$. All PCR amplicons were cleaned using AxyPrep DNA Gel Extraction Kit (Axygen Biotechnology, Hangzhou, Zhejiang, China). All amplicons were sequenced from both sides using PCR primers. The PCR products were run on an ABI 3700 sequencer (Applied Biosystems, Foster City, CA, USA). Sequences were deposited with GenBank under the accession numbers JQ639756 and JQ639766.

\section{Phylogenetic analyses}

A number of SSU and LSU sequences of dinoflagellates were downloaded from GenBank. Perkinsus marinus (Mackin, Owen \& Collier) Levine was used as outgroup in the SSU and LSU phylogenies. After the elimination of identical and apparently erroneous sequences, we created two sets of alignments by Clustal X (v1.8) (Thompson et al. 1997) and Bioedit (v7.0.9.1) (Hall 1999). The SSU and LSU alignments consisted of 44 sequences with 1,607 characters, and 54 sequences with 526 characters, respectively. We analyzed conversion / transversion and genetic distances using MEGA (v4.0.0.4103) (Tamura et al. 2007).

Phylogenies were estimated using maximum likelihood (ML) and Bayesian inference (BI) as implemented in RAxML (v7.2.6) (Stamatakis 2006) and MrBayes (v3.1.2) (Huelsenbeck and Ronquist 2001). The program jModelTest (v2.1.5) was used to explore the model of sequence evolution that best fits the data set by the Akaike information criterion (Darriba et al. 2012). In ML analyses, nodal support was assessed using 1,000 nonparametric bootstrap replicates. All Bayesian Markov Chain Monte Carlo 

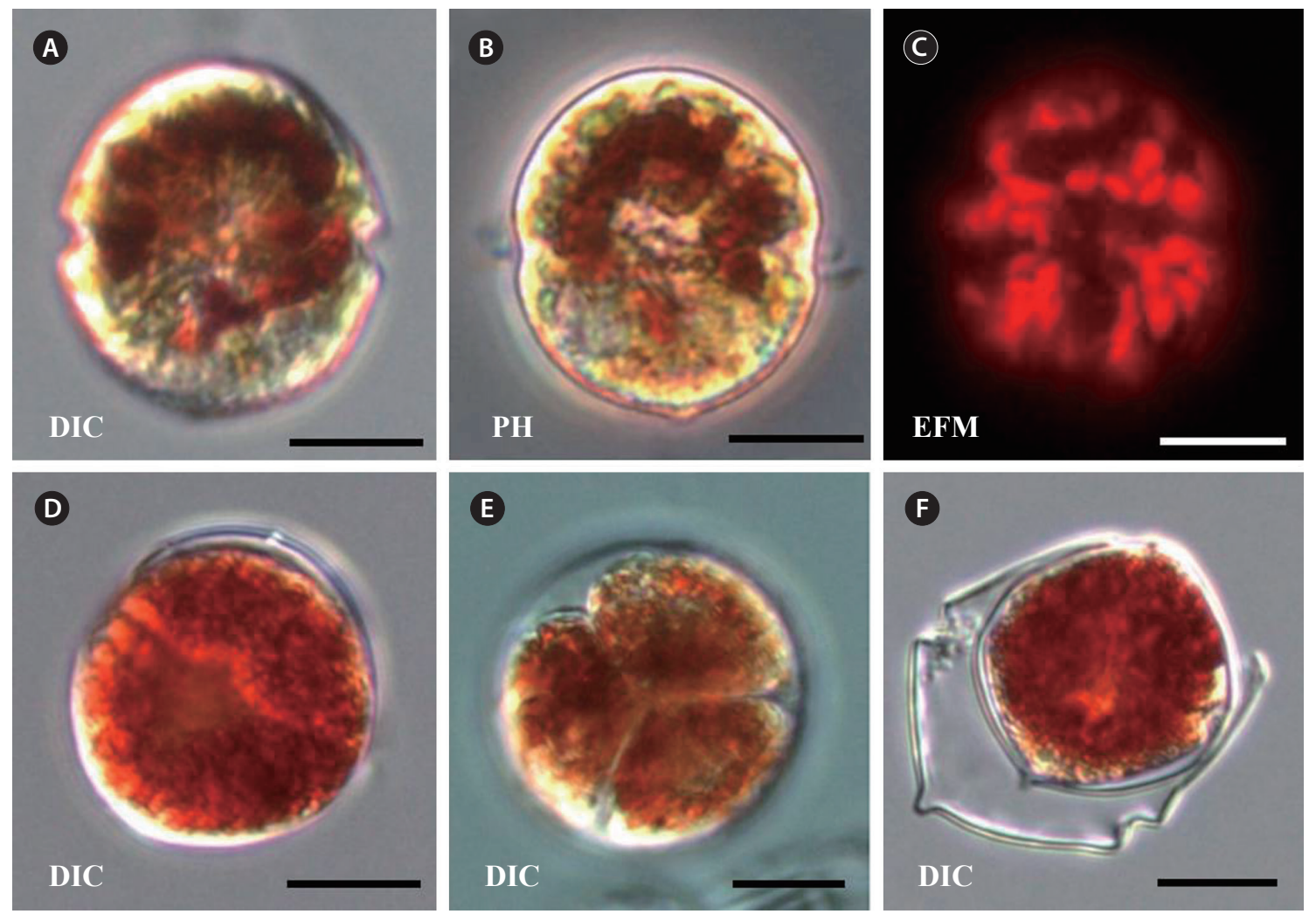

Fig. 3. Light micrographs of Tovellia diexiensis in Baishihai Lake. (A \& B) Vegetative cell. (C) Vegetative cell, ventral view showing autofluorescence of numerous discoid chloroplasts. (D) Vegetative cell, showing the presence of numerous red-pigmented bodies masking the chloroplasts. (E \& F) Cell division. DIC, differential interference contrast; EFM, epifluorescence microscopy; PH, phase contrast. Scale bars represent: A-F, $10 \mu \mathrm{m}$.

(MCMC) analyses were run with seven Markov chains (six heated chains, one cold) for 1,000,000 generations. Trees were sampled every 100 generations. We obtained posterior probability $(\mathrm{PP})$ values for the branching patterns in BI trees as well as bootstrap (bootstrap support value, BP) values in ML trees. The evolutionary models used in ML and BI analyses for SSU and LSU phylogenies were GTR + $\mathrm{I}+\mathrm{G}$ and TIM1 + I + G, respectively.

\section{RESULTS}

\section{Tovellia diexiensis Q. Zhang et G. X. Liu sp. nov.}

Diagnosis. Cell ovoid or nearly spherical, slightly dorsoventrally flattened. Epi- and hypotheca are usually hemispherical. The hypotheca often bears a short antapical spine. The theca consists many plates which are usually quadrilateral, pentagonal or hexagonal. The cingulum is median, descending, the ends displaced one cingulum width. The cell contains numerous yellowish-green dis- coid chloroplasts. However, the cell is usually bright red due to the presence of numerous red-pigmented bodies, which often mask the chloroplasts. The nucleus is located in the hypocone. A red eyespot is situated in the sulcus. Cells measure 20-32 $\mu \mathrm{m}$ in length, $16-24 \mu \mathrm{m}$ in width.

Holotype. SC-201101a (HBI), Baishihai Lake, collected by Qi Zhang on Aug 20, 2011. The sample is kept in 10\% formalin in the Freshwater Algal Herbarium (HBI), Institute of Hydrobiology, Chinese Academy of Sciences, Wuhan, Hubei, China. The holotype material was the source of SSU, LSU, internal transcribed spacer, and plastid-encoded 23S rDNA deposited as GenBank accession numbers JQ639766, JQ639756, JQ639774, and JQ639747, respectively. Figs $3 \mathrm{~A}$ and $4 \mathrm{E}-\mathrm{H}$ illustrated cells from this sample.

Type locality. Baishihai Lake, Sichuan Province, PR China (32 $\left.06^{\prime} 31^{\prime \prime} \mathrm{N}, 103^{\circ} 36^{\prime} 53^{\prime \prime} \mathrm{E}\right)$.

Etymology. 'diexiensis' is derived from Baishihai Lake being one of Diexi barrier lakes, created by the 1933 Diexi earthquake $(M=7.5)$ in Diexi Town, Sichuan Province. 

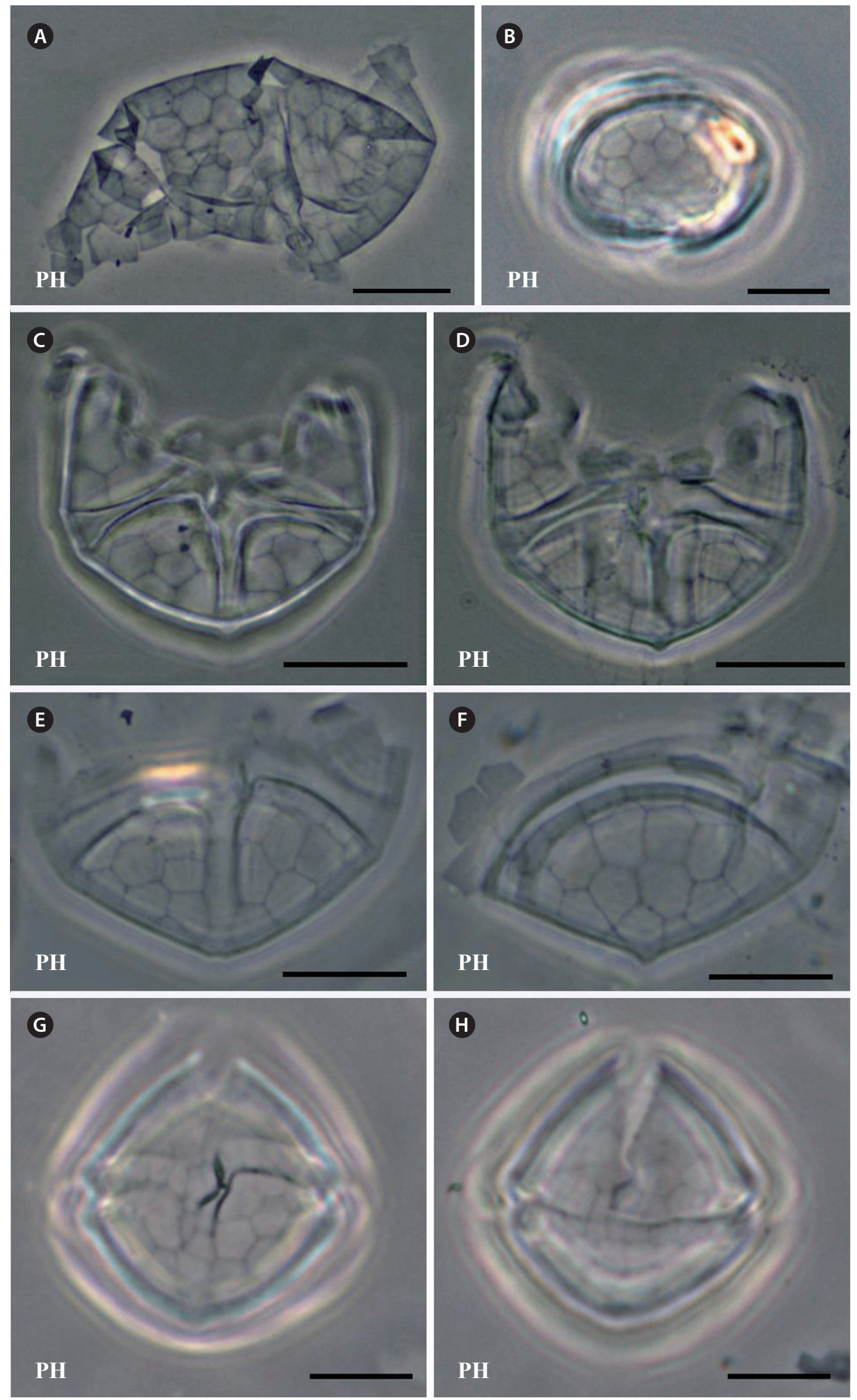

Fig. 4. Light micrographs of amphiesmal plates of Tovellia diexiensis. (A \& B) Platelets in apical view. (C \& E) Hypothecal platelets in ventral view. (D \& F) Hypothecal platelets of dorsal view. (G) Hypothecal platelets in ventral view, showing small platelets in the sulcus. (H) Platelets in ventral view, showing some epithecal platelets. $\mathrm{PH}$, phase contrast. Scale bars represent: $\mathrm{A}-\mathrm{H}, 10 \mu \mathrm{m}$. 


\section{Morphological observations}

Live motile cells were very fragile. They were ovoid or nearly spherical, blood-red in color (Fig. 3A \& B), and slightly dorsoventrally compressed. They measured 20-32 $\mu \mathrm{m}$ in length, and 16-24 $\mu \mathrm{m}$ in width $(\mathrm{n}=30)$. The lefthanded cingulum was located in the middle of the cell and displaced by about one cingulum width. Usually cells had a hemispherical episome and a broadly rounded hyposome with a very short antapical spine (Fig. 3B). The cell periphery contained numerous small yellowishgreen discoid chloroplasts (Fig. 3A \& C). The nucleus was located in the posterior part of the cell. A red eyespot was situated in the sulcus (Fig. 3A \& B). Cells were bright red due to the presence of numerous distinctly red-pigmented bodies which masked the chloroplasts (Fig. 3D-F). These bodies were usually accumulated in the episome. In the immobile stage they usually filled the entire cell (Fig. 3E \& F). Asexual reproduction occurred in the immobile stage, usually giving origin to four cells. The division cell lost their flagella, increased in size and became more round. Cleavage furrows eventually became visible in the peripheral cytoplasm. The four daughter cells already formed inside the division cell, and then would be released from the immobile cell (Fig. 3E).

The cells were covered by many quadrilateral, pentagonal or hexagonal amphiesmal plates arranged in latitudinal rows, four to five on the episome and four on the hyposome (Fig. 4A-F). The epi- and hyposome each comprised $c .40$ plates, each plate measuring 3-6 $\mu \mathrm{m}$ across. The cingulum comprised one series of about 20 plates, but the exact number was not determined. The sulcus comprised 6-8 small platelets (Fig. 4G). The sulcus extended to the antapical plate. The small antapical spine on the hyposome was formed by antapical platel"' and 2"'” (Fig. 4D \& F).

\section{Pigment analyses}

HPLC analyses demonstrated the presence of the following pigments in T. diexiensis: peridinin, dinoxanthin, diadinoxanthin, astaxanthin, chlorophyll $c 2$, lutein, echinenone, astaxanthin diester, adonixanthin, and $\beta$-carotene (Fig. 5). Astaxanthin and its diester were very prominent in the pigment analyses.

\section{Phylogeny of Tovellia}

Most SSU and LSU phylogenies had weakly defined backbone topologies but several well-supported internal

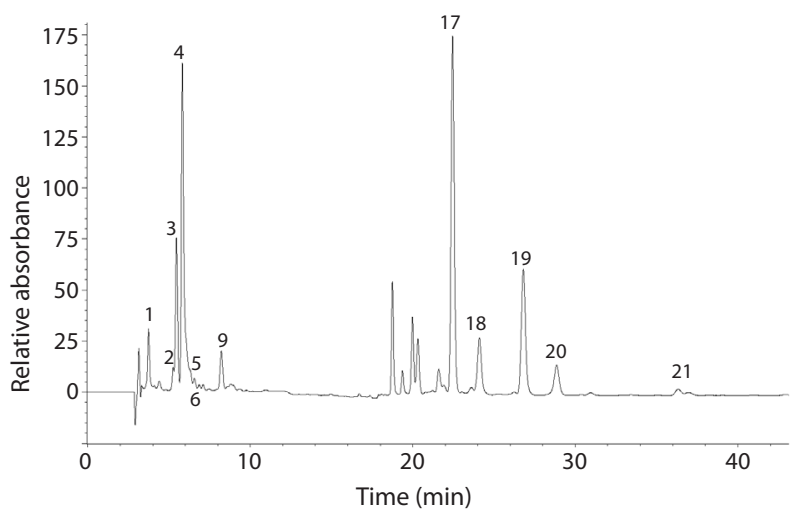

Fig. 5. Pigment profile of Tovellia diexiensis obtained from Baishihai Lake and analyzed by high performance liquid chromatography. Peaks were identified by typical retention time and absorption spectra compared with their respective standards compounds or previous reports: (1) peridinin; (2) dinoxanthin; (3) diadinoxanthin; (4) astaxanthin; (5) chlorophyll c2; (6) lutein; (9) echinenone; (17-19) astaxanthin diester; (20) adonixanthin; (21) $\beta$-carotene.

clades. In both SSU and LSU phylogenies, T. diexiensis affiliated closely with the family Tovelliaceae, comprising the genus Tovellia, Jadwigia, and Bernardinium (Figs 6 \& 7). In LSU phylogenies, all Tovelliaceae species clustered into a monophyletic clade, albeit with low support values (BP and PP $<50 \%$ or 0.50 ) (Fig. 7). LSU phylogenies supported highly the monophyly of the genus Tovellia (BP $=100 \%, \mathrm{PP}=1.00$ ), including T. sanguinea, T. aveirensis Pandeirada, Craveiro, Daugbjerg, Moestrup \& Calado, $T$. coronata (Wołoszyńska) Moestrup, Lindberg \& Daugbjerg and $T$. diexiensis. T. diexiensis formed a sister taxon to $T$. sanguinea $(\mathrm{BP}=92 \%, \mathrm{PP}=1.00)$. The two other groups of woloszynkioids, including Group II (Biecheleria, Symbiodinium, and Polarella) and Group III (Borghiella and Baldinia), formed sister groups in all analyses ( $\mathrm{BP}=87 \%$ and $\mathrm{PP}=1.00$ in SSU phylogenies; $\mathrm{BP}<50 \%$ and $\mathrm{PP}=0.66$ in LSU phylogenies) (Figs 6 \& 7).

Table 1 shows the sequence divergence estimates. The highest sequence divergences were seen in all pairwise comparisons between Jadwigia / Bernardinium and Tovellia species (ranging from 0.334-0.406 based on p-values and 0.451-0.604 based on Kimura-2-parameter values). The divergence between $T$. diexiensis and other Tovellia species was 0.184-0.274 based on p-values and 0.212-0.343 based on Kimura-2-parameter model. The smallest divergence estimate for $T$. diexiensis was seen when comparing T. diexiensis and T. coronata. The differences in the number of nucleotid bases between the two closely related species was $118 \mathrm{bp}$. 


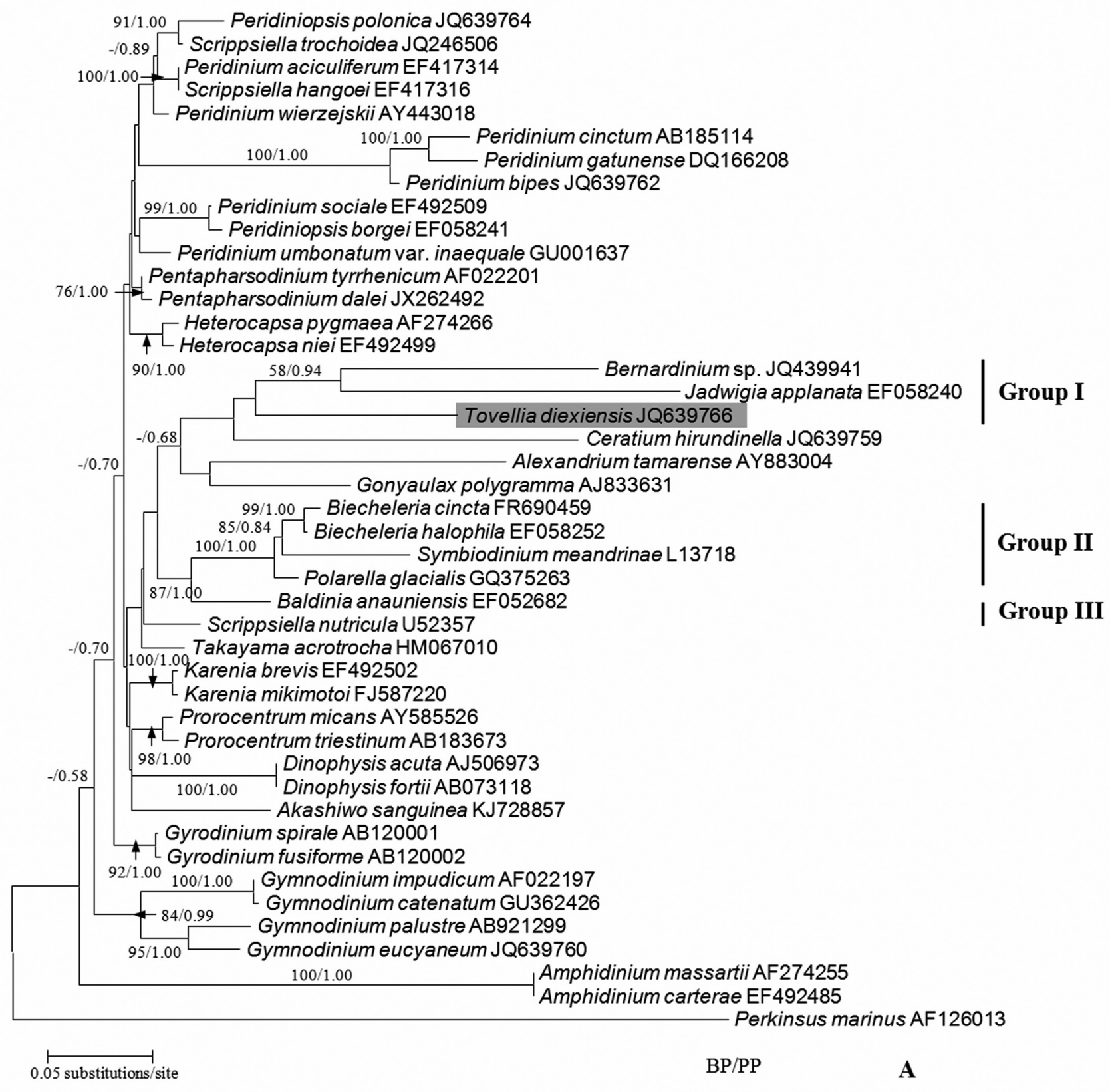

Fig. 6. Maximum likelihood phylogenetic tree constructed from dinoflagellate small subunit ribosomal DNA sequences. Numbers at nodes represent bootstrap support values (BP) / posterior probabilities (PP) from maximum likelihood and Bayesian inference, respectively. Only values above $50 \%$ or 0.50 are shown. The sequences obtained from our study are shaded gray. Woloszynskioids assigned to groups I-III (sensu Lindberg et al. 2005) have been pointed out in the trees.

\section{Ecology}

During the bloom-forming period, the causative species of Tovellia was examined in Baishihai Lake on Sep 1, 2005. The cell density of Tovellia ranged from $0.64 \times 10^{5}$ to $9.15 \times 10^{5}$ cells $\mathrm{L}^{-1}$ at different sites (Table 2 ). T. diexiensis occurred in large numbers at the surface of the lake, resulting in a very characteristic blood-red color of the water. Cell density was highly heterogeneous between different sites. Higher cell densities $\left(6.91 \times 10^{5}-9.15 \times 10^{5}\right.$ cells $\mathrm{L}^{-1}$ ) were found at the west side of the lake (sites IIII), and lower densities at the east side of the lake $(0.98$ $\times 10^{5}$ and $0.64 \times 10^{5}$ cells $\mathrm{L}^{-1}$ at sites IV and $\mathrm{V}$, respectively) (Table 2). Similarly, the chlorophyll- $a$ concentrations at the west side of the lake (sites I-III) were higher than at the east side of the lake (sites IV and V) (Table 2). During 


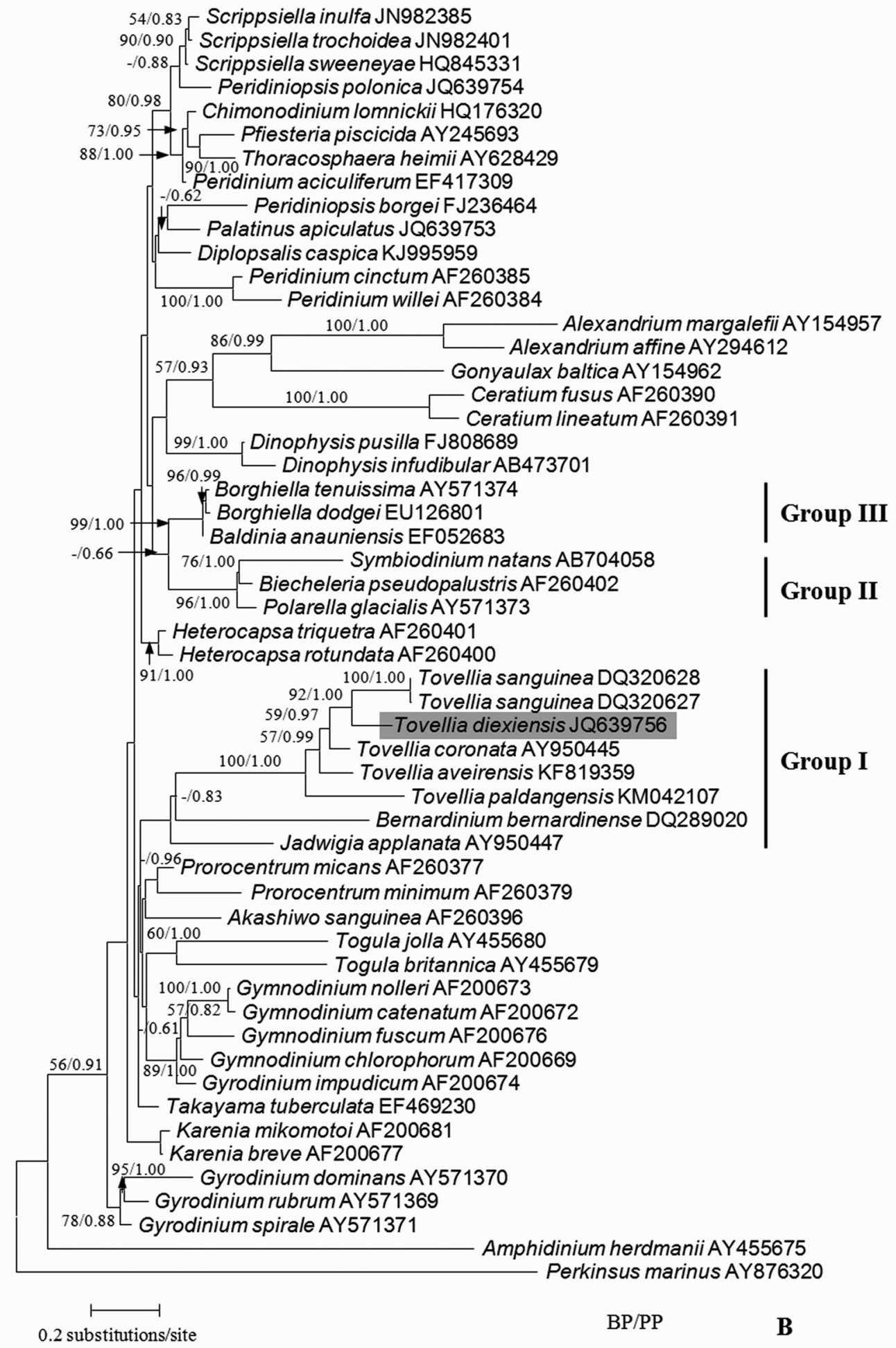

Fig. 7. Maximum likelihood phylogenetic tree constructed from dinoflagellate large subunit ribosomal DNA sequences. Numbers at nodes represent bootstrap support values (BP) / posterior probabilities (PP) from maximum likelihood and Bayesian inference. Only values above 50\% or 0.50 are shown. The sequences obtained from our study are shaded gray. Woloszynskioids assigned to groups I-III (sensu Lindberg et al. 2005) have been pointed out in the trees. 
the blooming period, TDP and TDN concentrations at the west side of the lake (sites I-III) were lower than at the east side of the lake (sites IV and V), and $\mathrm{NH}_{4}-\mathrm{N}$ concentrations at the west side of the lake (sites I-III) were higher than at the east side of the lake (sites IV and V) (Table 2).

\section{DISCUSSION}

\section{Identification of the organisms and pigments}

Considering cell shape and the arrangement of thecal plates, observations using light microscopy revealed that the bloom-forming organisms in Baishihai Lake belonged to a woloszynskioid dinoflagellate. Although some im- portant morphological characteristics remain uncertain, including cyst type and the presence of an apical line of plates, morphological and molecular analyses indicated that the speciesis closely related to freshwater Tovellia species. Comparison of vegetative-stage cells indicated that $T$. diexiensis differed morphologically from the other recorded Tovellia species (Table 3). T. diexiensis, T. coronata, and T. sanguinea have numerous small red droplets in the cytoplasm, that give the cells a characteristic red color (Lindberg et al. 2005, Moestrup et al. 2006), but $T$. diexiensis differed from the other red species of Tovellia in cell size, chloroplast arrangement and the arrangement of platelets. In particular, motile cells of T. diexiensis had a small characteristic antapical spine formed by antapical plates1'"' and 2'"'. Therefore, we referred to it as a new

Table 1. Sequence divergences of some Tovelliaceae species based on 673 LSU rDNA nucleotides

\begin{tabular}{|c|c|c|c|c|c|c|c|c|}
\hline & $\begin{array}{l}\text { T. diexiensis } \\
\text { JQ639756 }\end{array}$ & $\begin{array}{l}\text { T. coronata } \\
\text { AY950445 }\end{array}$ & $\begin{array}{l}\text { T. sanguinea } \\
\text { DQ320628 }\end{array}$ & $\begin{array}{c}\text { T. sanguinea } \\
\text { DQ320627 }\end{array}$ & $\begin{array}{c}\text { T. aveirensis } \\
\text { KF819359 }\end{array}$ & $\begin{array}{l}\text { T. paldangensis } \\
\text { KM042107 }\end{array}$ & $\begin{array}{c}\text { J. applanata } \\
\text { AY950447 }\end{array}$ & $\begin{array}{l}\text { B. bernardinense } \\
\text { DQ289020 }\end{array}$ \\
\hline $\begin{array}{l}\text { Tovellia diexiensis } \\
\text { JQ639756 }\end{array}$ & - & 0.212 & 0.224 & 0.224 & 0.230 & 0.343 & 0.451 & 0.571 \\
\hline $\begin{array}{l}\text { T. coronata } \\
\text { AY950445 }\end{array}$ & 0.184 & - & 0.251 & 0.256 & 0.193 & 0.299 & 0.451 & 0.575 \\
\hline $\begin{array}{l}\text { T. sanguinea } \\
\text { DQ320628 }\end{array}$ & 0.192 & 0.212 & - & 0.003 & 0.258 & 0.365 & 0.476 & 0.600 \\
\hline $\begin{array}{l}\text { T. sanguinea } \\
\text { DQ320627 }\end{array}$ & 0.192 & 0.215 & 0.003 & - & 0.258 & 0.362 & 0.483 & 0.604 \\
\hline $\begin{array}{l}\text { T. aveirensis } \\
\text { KF819359 }\end{array}$ & 0.195 & 0.168 & 0.217 & 0.217 & - & 0.316 & 0.480 & 0.580 \\
\hline $\begin{array}{l}\text { T. paldangensis } \\
\text { KM042107 }\end{array}$ & 0.274 & 0.241 & 0.287 & 0.285 & 0.254 & - & 0.545 & 0.596 \\
\hline $\begin{array}{l}\text { Jadwigia } \\
\text { applanata } \\
\text { AY950447 }\end{array}$ & 0.336 & 0.334 & 0.347 & 0.350 & 0.347 & 0.381 & - & 0.559 \\
\hline $\begin{array}{l}\text { Bernardinium } \\
\text { bernardinense } \\
\text { DQ289020 }\end{array}$ & 0.391 & 0.394 & 0.404 & 0.406 & 0.394 & 0.404 & 0.386 & - \\
\hline
\end{tabular}

Pairwise uncorrected p-distances are given below the diagonal, and distance values calculated using Kimura-2-parameter model are given above the diagonal.

LSU, large subunit ribosomal DNA.

Table 2. Environmental parameters, chlorophyll-a concentration and dinoflagellate abundance at different sites in Baishihai Lake

\begin{tabular}{lccccc}
\hline & Site I & Site II & Site III & Site IV & Site V \\
\hline DCD $\left(\times 10^{5} \mathrm{cells} \mathrm{L}^{-1}\right)$ & 7.82 & 9.15 & 6.91 & 0.98 & 0.64 \\
Cond $\left(\mu \mathrm{s} \mathrm{cm}^{-1}\right)$ & 388.8 & 267.0 & 412.2 & 221.5 & 205.4 \\
$\mathrm{Chl} a\left(\mu \mathrm{g} \mathrm{L}^{-1}\right)$ & 4.25 & 3.79 & 3.04 & 2.52 & 1.66 \\
TDP $\left(\mathrm{mg} \mathrm{L}^{-1}\right)$ & 0.0095 & 0.0095 & 0.0177 & 0.0258 & 0.0544 \\
$\mathrm{PO}_{4}-\mathrm{P}\left(\mathrm{mg} \mathrm{L}^{-1}\right)$ & 0.0019 & 0.0019 & 0.0143 & 0.0061 & 0.0019 \\
$\mathrm{TDN}_{\left(\mathrm{mg} \mathrm{L}^{-1}\right)}$ & 0.3866 & 0.4329 & 0.4051 & 0.4514 & 0.4330 \\
$\mathrm{NH}_{4}-\mathrm{N}\left(\mathrm{mg} \mathrm{L}^{-1}\right)$ & 0.3633 & 0.1850 & 0.4035 & 0.1505 & 0.1793 \\
\hline
\end{tabular}

$\mathrm{DCD}$, dinoflagellate cell density; Cond, conductivity; $\mathrm{Chl} a$, chlorophyll- $a$ concentration; TDP, total dissolved phosphorus; $\mathrm{PO}_{4}-\mathrm{P}$, phosphate; TDN, total dissolved nitrogen; $\mathrm{NH}_{4}-\mathrm{N}$, ammonium nitrogen. 


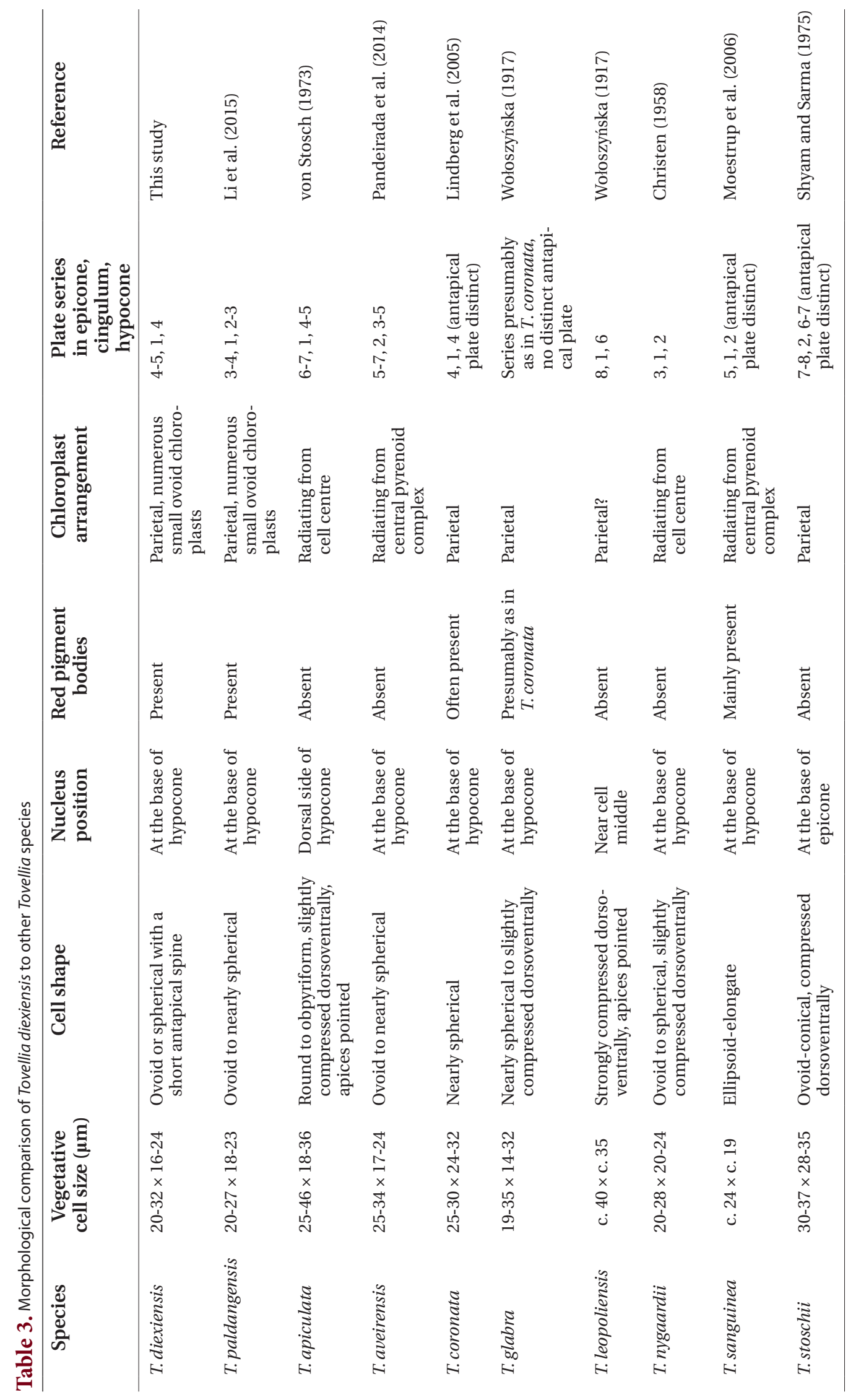


species T. diexiensis based on both morphological and molecular evidence.

Astaxanthin and its esters are rare in dinoflagellates. $T$. diexiensis produced high amount of astaxanthin-related carotenoids, accompanied by minor amounts of more typical dinoflagellates pigments such as chlorophyll $c 2$, peridinin, diadinoxanthin, dinoxanthin, and $\beta$-carotene. Astaxanthin-related carotenoids were responsible for the red color of the cells. The original name of the organism causing reddening of Lake Tovel in Italy, Glenodinium sanguineum, and used in numerous publications, is an illegitimate homonym and Moestrup et al. (2006) described it as a new species, Tovellia sanguinea. The dinoflagellate from Lake Tovel produced high amounts of astaxanthin and its esters, the first report of astaxanthin esters as major pigments in dinoflagellates and over-expressed in comparison to the light-harvesting carotenoid peridinin (Frassanito et al. 2006). However, the pigment responsible for another red Tovellia species, T. coronata remains uncertain, and astaxanthin was not identified in pigment analyses (Lindberg et al. 2005).

\section{Phylogenetic position of Tovellia}

Together with morphological and ultrastructural data, and type of resting cyst, phylogenetic analyses indicated that the species in the genus Woloszynskia erected by Thompson (1951) belonged to several genera (Lindberg et al. 2005). The genus Woloszynskia was found to comprise four or more genera, belonging to provisionally designated groups I-III (Moestrup et al. 2006). As Moestrup et al. (2008) noted, group I was remotely related to groups II and III, and the latter two occupied sister group positions in our phylogenetic trees. All members of group I were transferred to the family Tovelliaceae, including Tovellia, Jadwigia, and Bernardinium (Lindberg et al. 2005). In members of group I, the eyespot is extraplastidial, and composed of non-membrane bound lipid globules, type C eyespot sensu Moestrup and Daugbjerg (2007). In our SSU and LSU phylogenies, the family Tovelliaceae was monophyletic. T. diexiensis affiliated to other Tovellia species with typical red color (T. sanguinea and T. coronata) in LSU phylogenies. In spite of a smaller sequence divergence between $T$. diexiensis and T. coronata than between T. diexiensis and T. sanguinea the latter two species clustered into a highly supported subclade (BP $=92 \%$ and $\mathrm{PP}=1.00$ in LSU phylogenies). As T. sanguinea in Lake Tovel in Italy, cells of T. diexiensis, accumulated astaxanthin and its esters, and both resulted of spectacular reddening of the water.

\section{Occurrence and ecology}

The first occurrence of spectacular "reddening of the waters" in Baishihai Lake was reported in the summer of 2001. In subsequent years, the phenomenon appeared regularly in summer, usually from mid-July to the end of August. The blood-red bloom often occurred at the west end of lake, where a big sacrifice white stone (called 'baishi') is located near the bank. The dinoflagellates in the Lake exhibited diel depth dispersion. Generally, towards the morning they tended to rise to the surface, and a population peak was often found close to the water surface around noon. The cells migrated to deeper water by late afternoon and dispersed throughout the water column at night.

Similarly, the former annual reddening of Lake Tovel in the Italian Alps (up to 1964) was caused by T. sanguinea (Moestrup et al. 2006). Lake Tovel (1,178 $\mathrm{m}$ a.s.l., $\mathrm{Z}_{\max }=$ $39 \mathrm{~m}, \mathrm{Z}_{\text {mean }}=19 \mathrm{~m}$, surface $\left.=382,500 \mathrm{~m}^{2}\right)$ is a temperate, meromictic, oligotrophic mountain lake $(\mathrm{TDP}=0.003$ $0.006 \mathrm{mg} \mathrm{L}^{-1}, \mathrm{NO}_{3}-\mathrm{N}=0.280-0.420 \mathrm{mg} \mathrm{L}^{-1}$, mean Secchi disk $=\sim 10 \mathrm{~m}$ in the euphotic zone) (Corradini et al. 2001). Although the distance between Baishihai Lake and Lake Tovel is very great, there are many similarities between the two lakes. Baishihai Lake (2,480 $\mathrm{m}$ a.s.l., $\mathrm{Z}_{\max }=80 \mathrm{~m}$, $\mathrm{Z}_{\text {mean }}=25 \mathrm{~m}$, surface $\left.=\sim 400,000 \mathrm{~m}^{2}\right)$ was also a temperate, meromictic, meso- or oligotrophic high-altitude deep lake. The two Tovellia species thus appear to prefer similar habitats. The spectacular "reddening of the waters" in Lake Tovel was reported first in 1875 (Bolognini 1877); unfortunately, the reddening phenomenon ceased suddenly in 1965 (Tomasi 1989). The sudden ceasing caused a lot of concern and many hypotheses were proposed to explain the disappearance of the blooms (Tomasi 1989). The most plausible theory refers to changes in the nutrient status of the lake (Cantonati et al. 2003), but it needs to be examined further.

The summer reddening of Lake Tovel, which originated from the melting of dead ice after the end of the last glaciation around the year 1200 following a land slide, ceased suddenly in 1964 (Cantonati et al. 2003). Lake Baishihai was formed in 1933 following an earthquake and reddening of the waters is more recent, having started occurring in 2001. There are striking ecological resemblances between Baishihai Lake and Lake Tovel. They are temperate, meromictic, meso- or oligotrophic, landslide-dammed, high-altitude deep lakes which suddenly redden in summer due to Tovellia blooms. The cause of the sudden appearance of Tovellia in Lake Baishihai, needs to be studied in detail. 


\section{ACKNOWLEDGEMENTS}

This work was financially supported by the National Natural Science Foundation of China (Grant No. 31670202). We thank Hu Jianlin and Tang Hongbo at the Research Group of Algae Taxonomy and Resources Utilization, Institute of Hydrobiology, Chinese Academy of Sciences (IHB, CAS) for sampling.

\section{REFERENCES}

Berman-Frank, I., Zohary, T., Erez, J. \& Dubinsky, Z. 1994. $\mathrm{CO}_{2}$ availability, carbonic anhydrase, and the annual dinoflagellate bloom in Lake Kinneret. Limnol. Oceanogr. 39:1822-1834.

Bolognini, N. 1877. Salita alla Cima Roma (300 m circa) il 26 agosto 1875. Annuario SAT, Milano, pp. 69-82.

Cantonati, M., Tardio, M., Tolotti, M. \& Corradini, F. 2003. Blooms of the dinoflagellate Glenodinium sanguineum obtained during enclosure experiments in Lake Tovel (N. Italy). J. Limnol. 62:79-87.

Christen, H. R. 1958. Gymnodinium nygaardi sp. nov. Ber. Schweiz. Bot. Ges. 68:44-49.

Corradini, F, Flaim, G. \& Pinamonti, V. 2001. Five years of limnological observations on Lake Tovel (1995-1999): some considerations and comparisons with past data. Proc. Ital. Assoc. Oceanol. Limnol. 14:209-218.

Darriba, D., Taboada, G. L., Doallo, R. \& Posada, D. 2012. jModelTest 2: more models, new heuristics and parallel computing. Nat. Methods 9:772.

Eker, E., Georgieva, L., Senichkina, L. \& Kideys, A. E. 1999. Phytoplankton distribution in the western and eastern Black Sea in spring and autumn 1995. ICES J. Mar. Sci. 56(Suppl.):15-22.

Frassanito, R., Flaim, G., Mancini, I. \& Guella, G. 2006. High production of unexpected carotenoids in Dinophyceae. Astaxanthin esters from the freshwater dinoflagellate Tovellia sanguinea. Biochem. Syst. Ecol. 34:843-853.

Fukuju, S., Takahashi, T. \& Kawayoke, T. 1998. Statistical analysis of freshwater red tide in Japanese reservoirs. Water Sci. Technol. 37:203-210.

Jiang, H., Mao, X., Xu, H., Yang, H., Ma, X., Zhong, N. \& Li, Y. 2014. Provenance and earthquake signature of the last deglacial Xinmocun lacustrine sediments at Diexi, East Tibet. Geomorphology 204:518-531.

Hall, T. A. 1999. BioEdit: a user-friendly biological sequence alignment editor and analysis program for Windows 95/98/NT. Nucleic Acids Symp. Ser. 41:95-98.

Huelsenbeck, J. P. \& Ronquist, F. 2001. MRBAYES: Bayesian inference of phylogenetic trees. Bioinformatics 17:754755

Ki, J. -S., Jang, G. Y. \& Han, M. -S. 2005. Integrated method for single-cell DNA extraction, PCR amplification, and sequencing of ribosomal DNA from harmful dinoflagellates Cochlodinium polykrikoides and Alexandrium catenella. Mar. Biotechnol. 6:587-593.

Li, Z., Shin, H. H. \& Han, M. -S. 2015. Morphology and phylogeny of a new woloszynskioid dinoflagellate Tovellia paldangensis sp. nov. (Dinophyceae). Phycologia 54:6777.

Lindberg, K., Moestrup, Ø. \& Daugbjerg, N. 2005. Studies on woloszynskioid dinoflagellates. I: Woloszynskia coronata re-examined using light and electron microscopy and partial LSU rDNA sequences, with description of Tovellia gen. nov. and Jadwigia gen. nov (Tovelliaceae fam. nov.). Phycologia 44:416-440.

Logares, R., Shalchian-Tabrizi, K., Boltovskoy, A. \& Rengefors, K. 2007. Extensive dinoflagellate phylogenies indicate infrequent marine-freshwater transitions. Mol. Phylogenet. Evol. 45:887-903.

Lorenzen, C. J. 1967. Determination of chlorophyll and pheo-pigments: spectrophotometric equations. Limnol. Oceanogr. 12:343-346.

Lund, J. W. G., Kipling, C. \& Le Cren, E. D. 1958. The inverted microscope method of estimating algal numbers and the statistical basis of estimations by counting. Hydrobiologia 11:143-170.

Marchesoni, V. 1959. La Val di Tovel e il “Lago Rosso”. Nat. Alp. 10:37-76.

Moestrup, Ø. \& Daugbjerg, N. 2007. On dinoflagellate phylogeny and taxonomy. In Brodie, J. \& Lewis, J. (Eds.) Unravelling the Algae. CRC Press, FL, pp. 215-230.

Moestrup, Ø., Hansen, G. \& Daugbjerg, N. 2008. Studies on woloszynskioid dinoflagellates III: on the ultrastructure and phylogeny of Borghiella dodgei gen. et sp. nov., a cold-water species from Lake Tovel, N. Italy, and on $B$. tenuissima comb. nov. (syn. Woloszynskia tenuissima). Phycologia 47:54-78.

Moestrup, Ø., Hansen, G., Daugbjerg. N., Flaim, G. \& D'Andrea, M. 2006. Studies on woloszynskioid dinoflagellates II: on Tovellia sanguinea sp. nov., the dinoflagellate responsible for the reddening of Lake Tovel, N. Italy. Eur. J. Phycol. 41:47-65.

Pandeirada, M. S., Craveiro, S. C., Daugbjerg, N., Moestrup, Ø. \& Calado, A. J. 2014. Studies on woloszynskioid dinoflagellates VI: description of Tovellia aveirensis sp. nov. (Dinophyceae), a new species of Tovelliaceae with spiny cysts. Eur. J. Phycol. 49:230-243.

Regel, R. H., Brookes, J. D. \& Ganf, G. G. 2004. Vertical migra- 
tion, entrainment and photosynthesis of the freshwater dinoflagellate Peridinium cinctum in a shallow urban lake. J. Plankton Res. 26:143-157.

Rodriguez, S., Couté, A., Tenhage, L. \& Mascarell, G. 1999. Peridiniopsis durandi sp. nova (Dinophyta), a new freshwater dinoflagellate causing red tides. Algol. Stud. 130:15-29.

Schlüter, L. \& Havskum, H. 1997. Phytoplankton pigments in relation to carbon content in phytoplankton communities. Mar. Ecol. Prog. Ser. 155:55-65.

Shyam, R. \& Sarma, Y. S. R. K. 1975. Woloszynskia stoschii and Gymnodinium indicum, two new freshwater dinoflagellates from India: morphology, reproduction and cytology. Plant Syst. Evol. 124:205-212.

Stamatakis, A. 2006. RAxML-VI-HPC: maximum likelihoodbased phylogenetic analyses with thousands of taxa and mixed models. Bioinformatics 22:2688-2690.

State Environmental Protection Bureau (SEPB). 2002. Methods of monitoring and analysis for water and wastewater. 4th ed. China Environmental Science Press, Beijing, pp. 200-285.

Tamura, K., Dudley, J., Nei, M. \& Kumar, S. 2007. MEGA4: molecular evolutionary genetics analysis (MEGA) software version 4.0. Mol. Biol. Evol. 24:1596-1599.

Thompson, J. D., Gibson, T. J., Plewniak, F., Jeanmougin, F. \& Higgns, D. G. 1997. The Clustal X windows interface: flexible strategies for multiple sequence alignment aided by quality analysis tools. Nucleic Acids Res. 25:4876-4882.

Thompson, R. H. 1951. A new genus and new records of fresh-water Pyrrophyta in the Desmokontae and Dinophyceae. Lloydia 13:277-299.

Tomasi, G. 1989. Dall'immaginario al plausibile. Nat. Alp. 40:1-72.

von Stosch, H. A. 1973. Observations on vegetative reproduction and sexual life cycles of two freshwater dinoflagellates, Gymnodinium pseudopalustre Schiller and Woloszynskia apiculata sp. nov. Br. Phycol. J. 8:105-134.

Wang, X. Q., Li, Y. R., Yuan, Y., Zhou, Z. \& Wang, L. S. 2014. Palaeoclimate and palaeoseismic events discovered in Diexi barrier lake on the Minjiang River, China. Nat. Hazard. Earth Sys. 14:2069-2078.

Wołoszyńska, J. 1917. Neue Peridineen-arten, nebst Bemerkungen über den Bau der Hülle bei Gymnodinium und Glenodinium. Bull. Int. Acad. Pol. Sci. Lett. Ser. B Sci. Nat. 17:114-122.

Xu, X. -N. \& Wang, L. -S. 2002. Mountain hazard caused by earthquake in Songping River upper Minjiang and its controlling. Chin. J. Geol. Hazard Control 13:31-35.

Yuan, J. -P., Chen, F., Liu, X. \& Li, X. -Z. 2002. Carotenoid composition in the green microalga Chlorococcum. Food Chem. 76:319-325.

Zhang, Q., Liu, G. \& Hu, Z. 2011. Morphological differences and molecular phylogeny of freshwater blooming species, Peridiniopsis spp. (Dinophyceae) from China. Eur. J. Protistol. 47:149-160.

Zhang, Z. S. \& Huang, X. F. 1991. The research methods for freshwater plankton. Science Press, Beijing, pp. 333-356. 